(C) 2016 IEEE. Personal use of this material is permitted. Permission from IEEE must be obtained for all other uses, in any current or future media, including reprinting/republishing this material for advertising or promotional purposes, creating new collective works, for resale or redistribution to servers or lists, or reuse of any copyrighted component of this work in other works. 


\title{
Flipped Classroom - Students as Producers
}

\author{
Tone Vold \\ Faculty of Business Administration \\ Hedmark University of Applied Sciences \\ Rena, Norway \\ tone.vold@hihm.no \\ Robin Braun \\ University of Technology Sydney \\ Sydney,Australia \\ $\underline{\text { Robin.braun@uts.edu.au }}$ \\ Daniela Lundesgaard \\ Faculty of Business Administration \\ Hedmark University of Applied Sciences \\ Rena, Norway \\ daniela.lundesgaard@hihm.no
}

Extended abstract - Flipped classroom is something that more and more teachers add to their teaching plans. To use video recordings of their lectures as a support for the students and then focus more on working with the curriculum in class has become a method that is adopted by an increasing number of lecturers.

In higher education the students are adults. This implies that it needs to be a form of lecturing adapted to adults. From the area of organizational learning, and from andragogy, the key to learning lies in motivation and the motivation is triggered by engagement that in its turn stems from involvement. However, involving the learner in their own learning process is also about "letting go" of the teachers' full control. But is it necessary to maintain control? Is it possible to view the undertaking as a learning experience also for the teacher/lecturer? What control should be executed and what can one let go of?

The research done at Hedmark University of Applied Sciences, show some interesting features. The courses have been "Learning Organizations" (autumn) and "Knowledge Management" (spring). The lectures have been in the form of streaming video and the course is organized as three full day seminars each semester/course. Each day has had a similar approach: a browse through the different chapters that are going to be discussed. Then follows solving assignments related to the presented topics, first in small groups, then in plenary. Before the lunch break, the students present suggestions towards possible new assignments. During the lunch break, the lecturer writes up the assignment using the input from the students. There is a quality check regarding the topics being within the scope of the seminar. After the lunch break, the students solve the assignment, first in small groups, then in plenary. The assignment and solution(s) are discussed using the following standard:

1. What did we learn from the assignment?
2. What did we learn from making the assignment?

3. Which issues raised in the assignment could be elaborated further, either as a mandatory assignment (fall) or an exam (fall and spring)?

It is important to be clear and unambiguous about the learning objective of the course. It is also important to keep the scope within the limitations of the main literature. (This does, however, not exclude added resources like research papers, external links, etc.)

Note also that there is a balance between the literature of the curriculum and the way the courses are taught. The course on "Learning Organizations" includes a section on how adults learn, and thus they are "convinced" about the method of teaching. The course "Knowledge Management" has the course "Learning Organizations" as a prerequisite, so it also "inherits" the way of lecturing/teaching/learning.

This involvement, the students claim, has contributed to enhancing their learning outcomes. The students seem to grow accustomed to the organization and "expectations" the program. Also the average grades from last fall have improved from an average grade of $\mathrm{C}$ to an average grade of $B$. The activity in the classroom has shifted from the front of the classroom to the whole classroom.

A few Observations made during this process are:

1. The students are far more strict than the lecturer

2. The students suggest wider assignments than suggested by lecturer

3. The lecturer receives numerous tips and hints to support creating new assignments

4. Even if it is not 6 hours lecturing, it is a demanding task to secure that the assignments 
and solutions at all times are within the framework of the learning objective

5. For the second and the third seminar, it is important to seek to include at least parts of the previous literature

The paper will detail the different issues tied to the process of this "flip" and seek to explain the findings using relevant theory.

Keywords- Flipped classroom, student activity, student involvement, learning objective, learning outcome, motivation

\section{INTRODUCTION}

Flipping the classroom is about organizing the teaching in order to activate and thereby increase motivation with the students. This paper describes taking a course from being a teacher dominated lecturing to a teacher facilitated "workshop".

This flip is in order to increase and enhance the learning outcome from the course. Activating the students and drawing on the student input and own experiences, will contribute towards making the learning more adapted to the students' needs and thus support enhancing the learning outcome.

The flip support the idea of how adults learn; by being included and activated [1-4]. Being activated will motivate the student to contribute with their own experiences and thus be able to learn from other students' experiences, not only from what is presented in the textbooks and by the teacher.

\section{THE COURSES - A BRIEF DESCRIPTION}

The courses that have been a subject of testing out flipping the classroom are called "Learning Organizations" and "Knowledge Management", both courses are taught in Norwegian to Norwegian speaking students. The courses are each on 7,5 ECTS, and "Learning Organizations" are taught in the autumn, and is a prerequisite for the course "Knowledge Management" taught the following spring.

The courses are taught seminar based. Three full days per semester (distributed throughout the semester) are allocated to physical meetings with the students. Previously these days have been used to lecture from the textbooks.

In the course "Learning Organizations" they also have a mandatory assignment that need to be passed in order to do their exam. The exam in "Learning Organizations" is a written assignment that they have one week to hand in electronically. In the course "Knowledge Management" the exam is a four hour (hand-)written assignment at the University.
The course "Learning Organizations" is about how to understand how organizations learn and how to facilitate for learning in organizations. The introduction on the first day is thus mostly about "how adults learn", as organizations consists of adults.

The course "Knowledge Management" builds on the curriculum from the course "Learning Organizations" and takes the concepts of organizational learning further within organizing and managing knowledge in organizations.

\section{THEORETICAL BACKDROP FOR THE ORGANIZING}

In this chapter presents the theory the structure of organizing the courses is based on. Firstly it is about how adult education separates from child education, secondly about how adults learn and thirdly about learning in organizations.

\section{A. Adult education versus child education}

Sharan B. Merriam and Ralph G. Brockett has defined adult education as: "...activities intentionally designed for the purpose of being about learning among those whose age, social roles, or self-perception define them as adults." [5] This definition covers what being an adult is about.

Previously it has been different attempts to define the difference between adult education and child education, as some of the definitions have failed to do the proper distinction. The best we have found is by Boyd from 1966 that makes a point out of for whom the knowledge is for. "It is no longer the case of asking what the model would do under the given conditions but what will I do and what should I do. This indicates a direct handling of subject matter in which no bridge between the learner and the learner is required. This in essence is the distinct difference adult and child-youth education" [6]. Here Boyd touches the core of what should be considered regarding all adult education; the purpose of the education need to be linked to the adult, whilst in child-youth education often involves a link to the teacher (the "model"). The questions that adults often ask are: "how is this useful for me?" and "how can I use this knowledge (in my work)?" This indicates that the adult is more concerned with what will support his or her use of the knowledge, rather than how "the model" (the teacher) can make use of it.

\section{B. How adults learn}

Adults learn in several ways, and may have different learning styles. Some learn best by listening or reading, some learn best by experiencing, and/or discussing. Some learn best by a combination of the different approaches.

The American pragmatist John Dewey early described how and why it was important to utilize earlier experiences for learning purposes. To build on previous experience would support the learning process, he advocated [7]. Also he 
opposed to the passive learning methods and was a strong believer in active learning methods $[8,9]$.

David A. Kolb has described the learning process of an active learning method; experiential learning [10]. The experiential learning cycle depicts how one can reflect upon and learn from experiences and construct own abstractions that form the basis for new experiencing.

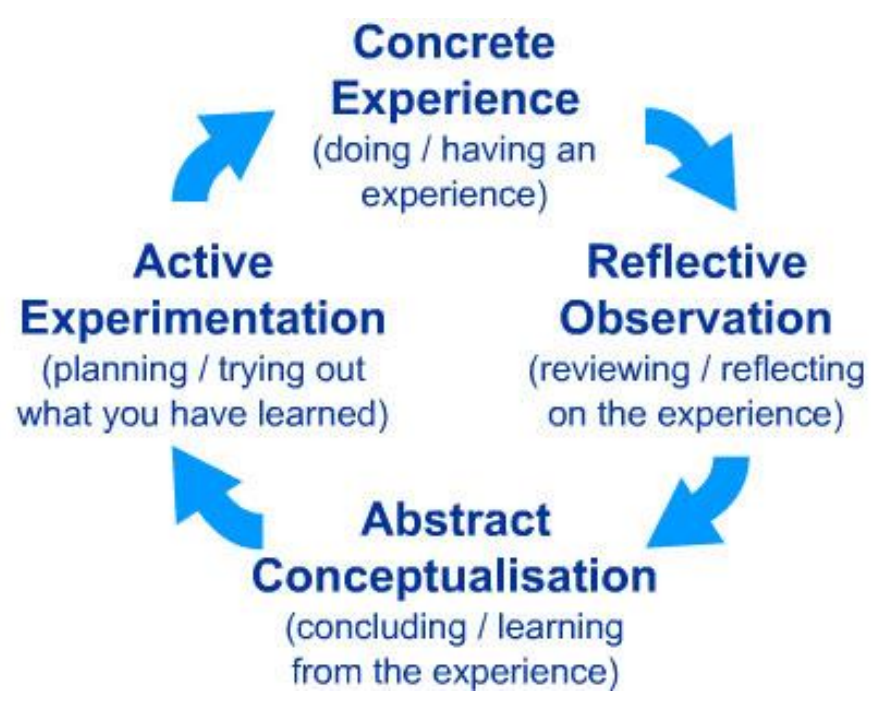

Figure 1 From: www.simplypsychology.com [11]: The Experiential Learning Cycle

The experiential learning cycle focuses on a persons' own experiences. It is however possible to learn from others' experiences. Not only focusing on ones' own experiences but also learn from others can foster cooperation and thus support social learning processes.

\section{Learning in organizations}

Learning in organizations is also about Knowledge Management (KM), and KM is about capturing, distributing and making sense and use of knowledge, as stated by $\mathrm{T}$. Davenport [12].

Organizing learning in an organization can be done in several ways. Internal courses, external courses, study groups, are some of the possibilities. In other words, individuals may learn in organizations, and they can bring knowledge to organizations. Organizations need to adapt to such as changes in market, innovations, user needs, to mention a few factors. The learning the organization goes through can be described as learning loops. Chris Argyris and Donald Schön have presented the ideas of single and double loop learning regarding organizational learning [13]. Single loop learning can be described as adjusting according to input, a "quick fix" that may (or may not) need to be repeated as the reason for the input is not addressed. The double loop then indicates that the reason is addressed and solved. The third loop introduced that has been about addressing diversity by using what is called diversity management [14]. Robert L. Flood and Norma Romm have defined triple loop learning as: “...being about the increase in the fullness and deepness of learning about the diversity of issues and dilemmas faced" [15].

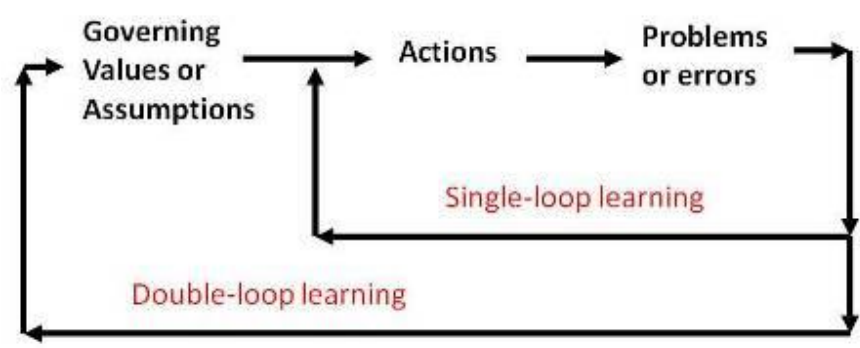

Figure 2 Single and double loop learning [13].

"Systems thinking" as described by Peter Senge [16] as the "fifth discipline" regarding learning organizations is also important. To understand what conditions that leads to what results is important in order to organize the double (and triple) loop regarding learning.

One of the four other disciplines is "personal mastery" which points to the individual in the organization. Without the workers learning, the organization will have less chances of surviving changes $[3,4]$.

Learning in an organization has thus been addressed by Jean Lave and Etienne Wenger by their introduction of "Communities of Practice" (CoP), Situated Learning and Legitimate Peripheral Participation [17]. The definition of a CoP is: "groups of people who share a concern or a passion for something they do and learn how to do it better as they interact regularly" [18]. Regarding working with CoP's there are some characteristics that are present: 1) a commitment to a domain identified by a shared practice interest, 2) the community consists of members that interact and learn cooperatively, and 3) the community members are practitioners who develop (over time) a shared pool of resources (like stories, experiences) [19].

Situated learning is about learning in a context. It is important that the learning is perceived as useful [20] and the context will mostly be work oriented.

Legitimate Peripheral Participation (LPP) is about learning from peers with more experience. To include newcomers in a community in order to bring them from the status as newcomers to the status of experts in a sociocultural practice[19], will be important in order to bring all participants to a best possible level of knowledge and/or skills. The difference between LPP and Apprenticeship is that opposed to LPP, Apprenticeship describes a different relationship between the learner and the "master". Often this is related to learning what can be described as "tacit knowledge" [21]. Tacit knowledge is knowledge that through social processes 
can be transferred, made explicit and internalized. Ikujiro Nonaka and Hirotaka Takeuchi developed a model for how tacit knowledge could be transferred through Sosialization, Externalization, Combination and Internalization, called the SECI-model [22].

\section{Summary from theory that will influence the organizing}

The theory presents some main features:

- Adults learn by being active

- Adults learn from own experiences

- Adults learn from others' experiences

- Adults learn in social settings

- Adults have different and often more learning styles

- $\quad$ The learning needs to be connected to their own work place

This does to a vast extent contradict the "ordinary" lecture and in the next section we will present how these points have been implemented in the courses.

\section{THE NEW STRUCTURE OF THE COURSES}

The new structure of the courses was introduced in its existing version in 2014 (autumn) and the data that is presented in this paper are from this and the three following semesters.

In this section we will present point by point from the previous section how the different learning from the theory has been incorporated in the new structure.

\section{A. Adults learn by being active}

Students need to be activated in order to be motivated and enhance the learning outcome. This has been implemented by making the students work in groups solving cases that has been developed for the course "Learning Organizations" [23]. Also the students are first encouraged to share experiences from their own organizations. The last seminar is however spent working on making the students actively contribute towards cases and assignments regarding their own exam. Even if it is the lecturers' (teachers') responsibility embraces deciding and producing the final exam, the activating of the students regarding this contribution has proved very useful.

\section{B. Adults learning from owns' and others 'experiences}

The students are as stated above encouraged to share their own experiences as input towards assignments and discussions on relevant theory in the seminars. By working with assignments during the seminars they will obtain more experience to reflect upon and the students are encouraged to solve the assignments several times between the physical seminars in order to obtain and "experience" different viewpoints. Solutions to the assignments are discussed in the seminar, but due to time constraints, there is little time to solve one case several times during the seminar.

\section{Adults learn in in social settings}

The students have to work in groups, sometimes in two's and sometimes in more than two. We seek to re-organize the groups, but also keeping in mind that the more they work together in groups, this also have another desired effect; they get to know each other and can thus form structures resembling Communities of Practice's also outside the formal seminars.

\section{Adults have different and often more learning styles}

In order to adapt the course to the different learning styles, each seminar is introduced by an "ordinary" short lecture using one way communication, but only introducing the highlights of the curriculum to be handled during that particular seminar. Also the whole "lecture" is recorded using Camtasia [24]. The recordings are made available in the Learning Management System used to administrate the courses at Hedmark University of Applied Sciences.

The seminars are not mandatory, although we strongly encourage the students to attend. It is thus possible to follow the course online without having to travel to the seminars.

\section{E. The learning needs to be connected to their own work place}

As previously stated, we encourage the students to bring forward experiences from their own work places. However, it is not possible to force students to share experiences. What we experience is that by sharing our own experiences with the students, they are also more prone to share with us and their fellow students. On the first of the three seminars per semester, a lot of time is spent discussing the importance of sharing and getting the opportunity of getting ones' own experiences discussed in order to learn more from them. It is also facilitated for using the others' experiences and relating these different experiences to own work practices.

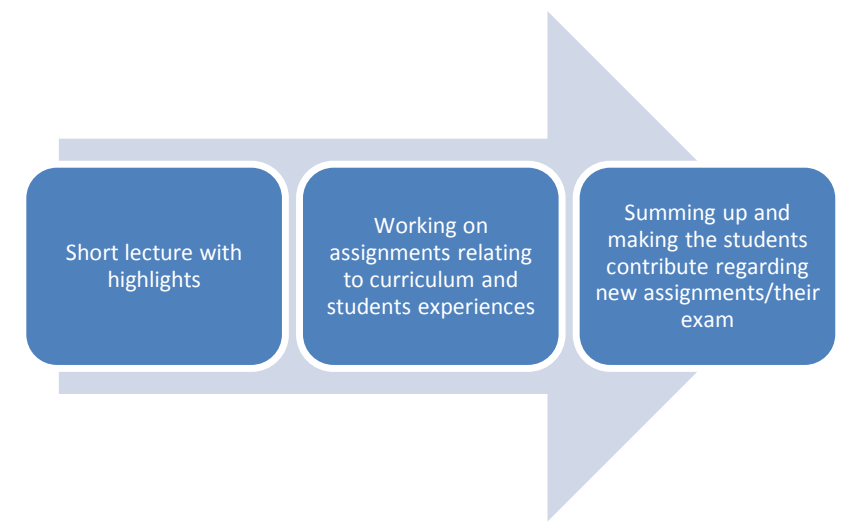

Figure 3 Structure of each seminar

The input from the students is used to form new assignments and may ultimately be used in their exams. This is a way of involving the students in their own learning process AND providing the link between the curriculum and their work life. 


\section{METHOD OF INQUIRY AND DATA ANALYZIS}

We need to be clear about our initial approach to changing the course; we needed a better approach to teach students about learning organizations and knowledge management. It was a contradiction to lecture for 6-8 hours about adults learning best by being active and involved in the learning processes. Although we have sought to be neutral in our data collection, it is important to state this possible bias. We still felt we could establish whether or not the students really benefit from this other structure and that they really did enhance their learning outcome.

In order to establish if the students have benefited from structuring the courses as flipped classrooms, we have undertaken interviews, both structured and semi-structured [25-28]. We have also used interview guides and conducted group interviews.

The lecturers own field notes have also been a part of the material in this mainly qualitative study [28-30].

We have also compared the exam results from the different years.

The analyzis has been conducted using the transcribed data to form categories and subcategories of data that has provided us with an increased understanding.

In order to secure and validate the data, we have sought as far as possible to do member checking [31].

\section{PRESENTATION OF RESULTS}

In this section the results will be presented and is divided in three parts; the exam results, the interviews and the field notes.

\section{A. Exam results}

As far as we have been able to establish from previous years exam results, the average grade has increased by one whole grade from $\mathrm{C}$ to $\mathrm{B}$. There is of course an uncertainty that is represented by the student group and how homogenous they really are with the students from previous years. However, it is a finding and discussing with sensors, they also confirm that they recognize an improvement in the exam results.

\section{B. Interviews - single and group}

The interviews show a development from the first seminar to the third. The interviews conducted after the first day show that the students are somewhat hesitant as they expected a full day lecture. They are not disgruntled or put off, but clearly state that this course represent a different approach to what they are used to from other courses and previous schooling. As they are not used to this way of working, they report on being uncertain about the learning outcome.

In the second and third seminar the students clearly state that this way of learning enhances their learning outcome. They are still hesitant towards being co-producers of assignments and exam.

\section{Field notes and observations}

The field notes show that there has been a lot of preparation regarding presenting the outlines of the courses and the teaching/learning processes that are to be undertaken. Just as we find in the interviews, there is a notable skepticism amongst the students in the first seminar. They do not know each other and it is thus a process of getting to know one another. They do however discuss and solve assignments.

In the second and third seminar the students seem more to adapt to the schedule and are active and involved. On the third seminar they are "buzzing" (word from field notes) and are active and share own experiences as well as discuss others, all relating back to the lessons (the text book curriculum).

\section{CONCLUSION AND FURTHER RESEARCH}

The conclusion, although with the uncertainties presented, are pointing towards an enhanced learning outcome from the new structure.

To activate the students in working with assignments and to involve them in the development of their new assignments, seems to have supported their learning process and enhanced their learning outcome from the courses. This is confirmed by a higher average grade, and from the interviews, and field notes.

This confirm what the theory has presented; the learning outcome will increase by activating students, by building on the students experiences and by involving them in their own learning process.

\section{A. Further research}

The process of making the students contribute towards producing assignments and exams has been very interesting and the process and feedback have intrigued us to explore this further. There is a potential of using this process as a way of recapitulating the curriculum. This needs to be explored further.

Also, this paper is focusing on very much on the seminars and the physical meeting with the students, and how to activate, involve and making them share experiences and co-reflect with their peers. But how can this be facilitated also between the seminars? How can we activate and involve our students between the seminars? 
Also; is it possible to present the streams that are now in a standard lecture format, in an improved version? Also, can the students be challenged to be co-producers of lectures online?

Lastly, it is necessary to investigate how these students do back in their work life. Even if they have reported on an enhanced learning outcome, what are the evidences of this being beneficial to their work place (which is why most of the students enrolled on the courses).

These are questions that we need to address in future projects. There is, however, no going back regarding the new structure of the courses. We claim that our research has confirmed that the students benefited from flipping the classroom.

\section{REFERENCES}

[1] M. S. Knowles, The modern practice of adult education : andragogy versus pedagogy. New York: Association Press, 1970.

[2] M. S. Knowles, Andragogy in action. San Francisco: Jossey-Bass, 1984.

[3] C. Filstad and G. Blåka, Learning in organizations. Oslo: Cappelen, 2007.

[4] E. J. Irgens, Dynamiske og laerende organisasjoner : ledelse og utvikling $i$ et arbeidsliv $i$ endring. Bergen: Fagbokforl., 2011.

[5] S. B. Merriam and R. G. Brockett. (1997). The profession and practice of adult education : an introduction (1st ed. ed.).

[6] R. A. Boyd, "A Psychological Definition of Adult Education," Adult Leadership, vol. 13, pp. 160-81, 1966.

[7] J. Dewey, Experience \& Education. New York: Touchstone, 1938.

[8] J. Dewey, Democracy and Education: Barnes \& Noble Books, 2005.

[9] D. F. Monk, "John Dewey and Adult Learning in Museums," Adult Learning, vol. 24, pp. 63-71, 2013.

[10] D. A. Kolb, Experiential learning: experience as the source of learning and development. Englewood Cliffs, N.J.: Prentice-Hall, 1984.

[11] S. McLeod. (2016, 16.06.). SimplyPsychology.com [web page]. Available: http://www.simplypsychology.org/

[12] T. H. Davenport, "Saving IT's soul: human-centered information management. (information technology)(includes related information on the use of human-centered information)," Harvard Business Review, vol. 72, p. 119, 1994.

[13] C. Argyris and D. Schön, Organizational Learning II. Theory, Method, and Practice New York: AddisonWesley Publishing Company, Inc., 1996.

[14] R. L. Flood and N. R. A. Romm, Diversity management : triple loop learning. Chichester: Wiley, 1996.
[15] R. L. Flood and N. R. A. Romm, "Contours of diversity management and triple loop learning," Kybernetes, vol. 25, pp. 154-163, 1996.

[16] P. M. Senge, The fifth discipline : the art and practice of the learning organization. London: Century Business, 1992.

[17] J. Lave and E. Wenger, Situated learning Legitimate peripheral participation. Cambridge: Cambridge University Press, 1991.

[18] Wenger-Traynor. (2016, 31.03). WengerTraynor.com [web page]. Available: http://wengertrayner.com/introduction-to-communities-of-practice/

[19] E. Wenger, Communities of practice: learning, meaning, and identity. Cambridge: Cambridge University Press, 1998.

[20] E. Wenger, "Regarding the term "situated"," T. Vold, Ed., Mail conversation ed, 2010.

[21] M. Polanyi, Den tause dimensjonen. New York: Doubleday, 1966.

[22] I. Nonaka and H. Takeuchi, The Knowledge-Creating Company: How Japanese Companies Create the Dynamics of Innovation. New York: Oxford University Press, 1995.

[23] $\quad$ A. Thomassen and T. Vold, Laerende organisasjoner : casesamling. Oslo: Protence, 2015.

[24] T. Corporation. (1995, 01.08.). https://www.techsmith.com/camtasia.html [web page].

[25] M. Dalen, Intervju som forskningsmetode. Oslo: Universitetsforl., 2011.

[26] N. K. Denzin and Y. S. Lincoln, The Sage handbook of qualitative research. Thousand Oaks, Calif.: Sage, 2005.

[27] K. Halvorsen, Å forske på samfunnet: en innføring $i$ samfunnsvitenskapelig metode. Oslo:

Bedriftsøkonomens forl., 1993.

[28] M. B. Postholm, Kvalitativ metode: en innforing med fokus på fenomenologi, etnografi og kasusstudier. Oslo: Universitetsforl., 2010.

[29] J. W. Creswell, Research Design: Qualitative, Quantitative, and Mixed Methods Approaches, 2nd ed. Thousand Oaks: Sage Publications, Inc, 2003.

[30] J. W. Creswell and V. L. P. Clark, Designing and Conducting Mixed Methods Reseach. Thousand Oaks, California, 2007.

[31] E. G. Guba and Y. S. Lincoln, Fourth generation evaluation. Newbury Park, Calif.: Sage, 1989. 